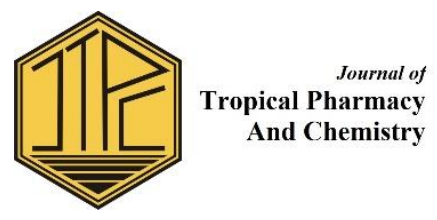

\title{
PENGARUH MEROKOK TERHADAP KEEFEKTIVITASAN TERAPI HIPERTENSI PADA PENDERITA HIPERTENSI PEROKOK DI EMPAT PUSKESMAS TAHUN 2017
}

\author{
Dna Raras Mardena*, Anjar Mahardian Kusuma \\ Kelompok Bidang Ilmu Farmasi-Klinik, Fakultas Farmasi \\ Universitas Muhammadiyah Purwokerto, Indonesia \\ *Corresponding author: dnamardena@gmail.com
}

\begin{abstract}
Hypertension is a chronic condition of the mesh where blood pressure rises above normalized blood pressure. This study aims to measure the effect of smoking on the effectiveness of hypertension therapy in patients with hypertension of smokers at Puskesmas I Sumbang, Puskesmas II Kembaran, Puskesmas Purwokerto Timur I, Puskesmas Purwokerto Selatan 2017. Type of study used prospective cohort, in terms of patient's blood pressure with drug consumption Single 1st, 10th day, 30th day to assess effectiveness. Data were analyzed univariat and bivariate through Chi-square test. The result showed that $p>0,05$ that $p=$ 0,361 showed that there was no significant difference in the effectiveness of hypertension therapy between group of non smoker hypertension and smoker hypertension. Does not affect the effectiveness of therapy statistically.
\end{abstract}

Keywords: Hypertension, Effectiveness, Amlodipine, Smoking

\begin{abstract}
ABSTRAK
Hipertensi adalah suatu kondisi mesis yang kronis dimana tekanan darah meningkat di atas tekanan darah yang disepakati normal. Penelitian ini bertujuan untuk mengukur pengaruh merokok terhadap keefektivitasan terapi hipertensi pada penderita hipertensi perokok di Puskesmas I Sumbang, Puskesmas II Kembaran, Puskesmas Purwokerto Timur I, Puskesmas Purwokerto Selatan Tahun 2017. Jenis penelitian yang digunakan kohort prospektiv, dengan mengukur tekanan darah pasien dengan konsumsi obat tunggal Amlodipin pada hari ke-1, hari ke-10, hari ke-30 untuk menilai keefetivitasan. Data dianalisis secara univariat dan bivariat melalui Uji Chi-square. Hasil penelitian menunjukan $p>0,05$ yaitu $p=0,361$ yang menunjukan tidak ada perbedaan yang bermakna keefektivitasan terapi hipertensi antara kelompok hipertensi tidak perokok dan hipertensi perokok. Kesimpulan merokok tidak mempengaruhi keefektivitasan terapi secara statistik namun memberikan dampak secara klinis.
\end{abstract}

Kata kunci : Hipertensi, Keefektivitas, Amlodipin, Merokok

Submitted on: $\quad 14$ July $2017 \quad$ Accepted on:20 Desember 2017

DOI: https://doi.org/10.25026/jtpc.v4i2.133

\section{PENDAHULUAN}

Hipertensi merupakan kondisi yang sering ditemukan pada pelayanan kesehatan primer dengan pravalensi sebesar 25,8\% [1]. Hipertensi dipengaruhi oleh beberapa faktor diantaranya adalah kebiasaan merokok. Indonesia menempati peringkat ke-3 dalam daftar 10 negara perokok terbesar di dunia dengan jumlah 65 juta perokok 
atau $28 \%$ per penduduk di bawah Cina dan India [2].

Menurut Narayana dan Sudhana (2013), Riskesdas (2013), dan Kurniati (2012), menyebutkan bahwa kejadian hipertensi dengan status merokok ada dengan jumlah kejadian sebanyak 52,2\% [3-5]. Jika merokok adalah salah satu faktor terjadinya hipertensi maka perlu adanya perhatian khusus terapi pada kelompok penderita hipertensi dengan status merokok, karena kebiasaan merokok akan berpengaruh pada peningkatan tekanan darah, sedangkan tekanan darah yang tidak terkontrol pada penderita hipertensi berpotensi mengalami penyakit berkelanjutan seperti, gagal ginjal, penyakit jantung koroner, stroke dan bahkan kematian.

Menurut Sedayu dan Baharuddin dalam terapi pada penderita hipertensi obat yang efektif dan paling sering digunakan pada terapi hipertensi adalah Amlodipin [6-7]. Amlodipin mampu menurunkan tekanan darah pada pasien hipertensi hingga sebesar 32,94/16,38 mmHg dibanding Kaptopril dan Hidroklortiazid. Melihat hal tersebut maka perlu ditelusuri mengenai efektivitas obat antihipertensi Amlodipin terhadap terapi hipertensi pada kelompok khusus hipertensi perokok.

Dari 39 puskesmas yang terletak di wilayah Kabupaten Banyumas, penderita hipertensi dengan kejadian tinggi ada pada Puskesmas I Sumbang, Puskesmas Purwokerto I Timur, Puskesmas II Kembaran, dan Puskesmas Purwokerto Selatan. Oleh karena itu keempat Puskesmas tersebut menjadi tempat penelitian [8].

Berdasarkan latar belakang diatas maka perlu dilakukan penelitian tentang pengaruh merokok terhadap keefektivitasan terapi amlodipin pada penderita hipertensi perokok di Empat Puskesmas di Kabupaten Banyumas.

\section{METODE PENELITIAN}

Jenis Penelitian deskriptif analitik dengan metode pengumpulan data kohort prospektif mencari hubungan antara variabel bebas (merokok) dengan variabel terikat (efektivitas terapi hipertensi).

Tempat dan Waktu Penelitian Penelitian dimulai. Penelitian ini dilaksanakan pada bulan Febuari sampai April 2017. Berlokasi di Wilayah Kerja Puskesmas I Sumbang, Puskesmas II Kembaran, Puskesmas Purwokerto Timur I, Puskesmas Purwokerto Selatan.

Kriteria inklusi, pasien hipertensi esensial lak-laki tidak perokok (kelmpok kontro) dan pasien hipertensi esensial laki-laki yang merokok (kelompok terpajan) dan merupakan pasien PROLANIS yang tercatat di Puskesmas I Sumbang, Puskesmas II Kembaran, Puskesmas Purwokerto Timur I, Puskesmas Purwokerto Selatan tahun 2017, Usia pasien $\geq 20$ tahun dan bersedia menjadi responden penelitian.

Kriteria ekslusi, pasien hipertensi dengan penyakit penyerta, pasien hipertensi yang mengalami infeksi sistemik, pasien hipertensi yang memiliki gangguan bicara dan pendengaran.

\section{HASIL DAN PEMBAHASAN}

Pada penelitian ini, obat antihipertensi yang digunakan adalah monoterapi tunggal yaitu amlodipin. Karakteristik responden dapat dilihat pada Tabel 1. Berdasarkan pada Tabel 1 menunjukan responden berusia $\geq 60$ tahun mendominasi jumlah responden yaitu sebanyak 64 orang $(83,1 \%)$, sedangkan berdasarkan usia mulai merokok sebanyak 20 orang $(55,1 \%)$ mulai merokok pada usia 10-19 tahun, dan berdasarkan frekuensi merokok sebanyak 19 orang $(52,8 \%)$ menghabiskan antara 10-20 rokok batang perhari. Jenis obat yang dikonsumsi 
semua pasien menggunakan obat antihipertensi tunggal yaitu amlodipin.

Tabel 2 menunjukan distribusi frekuensi tekanan darah sistolik dan diastolik responden pada hari ke-1, hari ke-10, dan hari ke-30 penelitian. Hasil penelitian meunjukan bahwa Amlodipin mampu menurunkan rerata tekanan darah sistolik pada pasien hipertensi tidak merokok sebesar 4,15 $\mathrm{mmHg}$, sedangkan pada tekanan diastolik mengalami kenaikan rerata sebesar 1,32 $\mathrm{mmHg}$.

Tabel 3 menunjukan hasil uji statistik uji Chi-Square dengan kemaknaan hasil perhitungan statistik menggunakan batas kemaknaan 0,05 sehingga nilai $\mathrm{p}<0,05$, namun nilai $\mathrm{p}>$ 0,05 yaitu $\mathrm{p}=0,361$ sehingga hasil analisis Uji Chis-quare menunjukan bahwa tidak ada perbedaan keefektivitasan terapi hipertensi amlodipin antara kelompok hipertensi tidak perokok dengan kelompok hipertensi perokok.
Berdasarkan pada Tabel $1 \mathrm{a}, 1 \mathrm{~b}$, $1 \mathrm{c}$, responden berusia $\geq 60$ tahun mendominasi jumlah responden yaitu sebanyak 64 orang $(83,1 \%)$. Hal ini sesuai dengan penelitian sebelumnya yang dilakukan Violata, Thaha, dan Dwinata (2015) yang menyatakan sebagian besar responden berada pada rentan usia 60 tahun. Hal ini juga sejalan dengan penelitian yang dilakukan Sarampang, Tjitrosantoso, dan Citraningtyas (2014) yang menyatakan bahwa resiko terkena hipertensi meningkat sejalan dengan bertambahnya usia. Penambahan usia terutama memasuki usia lansia dijumpai berbagai penurunan fungsi organ tubuh sebagi akibat dari proses aging, diantaranya terjadinya penurunan daya elastisitas pembuluh darah yang menyebabkan arteri dan aorta kehilangan daya menyesuaikan diri dengan aliran darah, dengan demikian semakin bertambah usia cenderung terkena hipertensi.

Tabel 1. Distribusi Frekuensi Karakteristik Responden Berdasarkan Usia, status merokok, Usia Mulai Merokok, Frekuensi Merokok, Jenis Obat yang dikonsumsi pada Pasien Hipertensi di 4 Puskesmas. $(N=77)$

\begin{tabular}{|c|c|c|}
\hline Karakteristik Responden & Frekuensi & Persentase (\%) \\
\hline \multicolumn{3}{|l|}{ a. Umur responden } \\
\hline 1) $\quad<60$ tahun & 13 & 16,9 \\
\hline 2) $\geq 60$ tahun & 64 & 83,1 \\
\hline \multicolumn{3}{|c|}{ b. Umur Responden Tidak Perokok } \\
\hline 1) $<60$ tahun & 6 & 14,6 \\
\hline 2) $\geq 60$ tahun & 35 & 85,4 \\
\hline \multicolumn{3}{|l|}{ c. Umur Responden Perokok } \\
\hline 1) $<60$ tahun & 7 & 19,4 \\
\hline 2) $\geq 60$ tahun & 29 & 80,6 \\
\hline \multicolumn{3}{|l|}{ d. Usia mulai merokok } \\
\hline 1) 10-19 tahun & 20 & 55,1 \\
\hline 2) 20-29 tahun & 12 & 33,3 \\
\hline 3) $\geq 30$ tahun & 4 & 11,1 \\
\hline \multicolumn{3}{|l|}{ e. Frekuensi Merokok } \\
\hline 1) $<10$ batang & 17 & 47,2 \\
\hline 2) $10-20$ batang & 19 & 52,8 \\
\hline 3) $>20$ batang & 0 & 0 \\
\hline \multicolumn{3}{|l|}{ f. Jenis Obat yang dikonsumsi } \\
\hline 1) Amlodipin & 77 & 100 \\
\hline Total & 77 & 100 \\
\hline
\end{tabular}


Pengaruh Merokok terhadap Keefektivitasan Terapi Hipertensi pada Penderita Hipertensi Perokok di Empat Puskesmas Tahun 2017

Tabel 2. Distribusi dan Frekuensi Tekanan Darah Sistolik dan Diastolik pada Pasien Hipertensi Tidak Perokok dan Pasien Hipertensi Perokok di 4 Puskesmas. $(N=77)$

\begin{tabular}{|c|c|c|c|c|}
\hline & & $\begin{array}{c}\text { TD } \\
\text { Hari ke-1 }\end{array}$ & $\begin{array}{c}\text { TD } \\
\text { Hari ke-10 } \\
\end{array}$ & $\begin{array}{c}\text { TD } \\
\text { Hari ke-30 } \\
\end{array}$ \\
\hline \multirow[t]{3}{*}{ a. } & $\begin{array}{l}\text { Hipertensi Tidak } \\
\text { Merokok }\end{array}$ & & & \\
\hline & 1) Sistolik (mmHg) & $145,07 \pm 0.448$ & $141,58 \pm 0,480$ & $140,92 \pm 0,498$ \\
\hline & 2) Diastolik (mmHg) & $84,63 \pm 0,506$ & $84,92 \pm 0,506$ & $85,95 \pm 0,504$ \\
\hline \multirow[t]{3}{*}{ b. } & Hipertensi Merokok & & & \\
\hline & 1) Sistolik (mmHg) & $152,63 \pm 0,500$ & $150,63 \pm 0,507$ & $151,25 \pm 0,494$ \\
\hline & 2) Diastolik (mmHg) & $87,58 \pm 0,500$ & $84,25 \pm 0,506$ & $86,55 \pm 0,507$ \\
\hline
\end{tabular}

Tabel 3. Keefektifitasan terapi hipertensi pada penderita hipertensi tidak perokok dan hipertensi perokok.

\begin{tabular}{|c|c|c|c|c|c|c|c|}
\hline \multirow[t]{3}{*}{ Keefektifitasan } & \multicolumn{4}{|c|}{$\begin{array}{c}\text { Tipe Perokok } \\
\end{array}$} & \multicolumn{2}{|c|}{ Total } & \multirow[t]{3}{*}{$\boldsymbol{P}$} \\
\hline & \multicolumn{2}{|c|}{ Tidak Perokok } & \multicolumn{2}{|c|}{ Perokok } & & & \\
\hline & $\mathrm{f}$ & $\%$ & $\mathrm{~F}$ & $\%$ & $\mathrm{f}$ & $\%$ & \\
\hline Efektif & 18 & 43,9 & 12 & 33,3 & 30 & 39 & \\
\hline Tidak Efektif & 23 & 56,1 & 24 & 66,7 & 47 & 61 & 0,343 \\
\hline Total & 41 & 100 & 36 & 100 & 77 & 100 & \\
\hline
\end{tabular}

Dari Tabel 1d dari hasil penelitian dapat diketahui bahwa dari 36 responden hipertensi perokok, sebanyak 20 orang $(55,1 \%)$ mulai merokok pada usia 10-19 tahun. Pada usia ini merupakan usia yang sangat awal untuk seseorang memulai aktivitas merokoknya yang dilakukan hingga sampai saat ini, padahal menurut Syazana semakin lama seseorang merokok maka tekanan darah seseorang akan semakin tinggi [10].

Dari data frekuensi merokok pada Tabel 1e dapat diketahui dari 36 responden hipertensi perokok, 19 orang $(52,8 \%)$ menghabiskan antara 10-20 rokok batang perhari.Hasil penelitian ini sejalan dengan penelitian sebelumnya seperti pada penelitian Syazana (2007) menyatakan semakin banyak jumlah rokok yang dihisap, maka rata-rata tekanan darah responden juga meningkat. Begitu juga dengan hasil penelitian Kurniati menyatakan bahwa semakin banyak jumlah rokok yang dihisap dalam setiap hari maka akan berpengaruh terhadap peningkatan tekanan darah [5]. Menurut Manik seseorang yang merokok lebih dari satu pak rokok sehari akan 2 kali lebih rentan terkena hipertensi daripada mereka yang tidak merokok [11]. Hal ini juga sejalan dengan hasil penelitian Riskesdas, dimana didapatkan $29,4 \%$ penduduk yang memiliki kebiasaan merokok di Indonesia menderita hipertensi [1].

Pada penelitian ini yang ditunjukan oleh Tabel if jenis obat yang dikonsumsi semua pasien menggunakan obat antihipertensi tunggal yaitu Amlodipine, hal ini sejalan dengan penelitian sebelumnya yang diteliti Smantummkul yang menyatakan bahwa golongan obat antihipertensi yang paling banyak digunakan adalah peresepan obat golongan Diuretik, golongan ACEI dan golongan CCB yaitu Amlodipine [12]. Penggunaan antihipertensi tunggal juga sejalan dengan penelitia Violita, Thaha dan Dwinata yang menyatakan bahwa mayoritas responden menggunakan jenis 
terapi antihipertensi tunggal atau mengkonsumsi 1 jenis obat tiap harinya yaitu sebanyak 113 orang $(84,2 \%)$ [13]. Amlodipin juga merupakan obat yang paling sering digunakan seperti pada penelitian sebelumnya oleh Sedayu (2015) menyatakan bahwa Amlodipine merupakan jenis obat yang paling sering digunakan yaitu sebesar $(44,27 \%)$ [6].

Penggunaan amlodipin dikarenakan kemampuannya yang segera menurunkan tekanan darah seperti pada penelitian sebelumnya, Nafrialdi menyatakan Amlodipin merupakan obat yang sangat bermanfaat mengatasi hipertensi darurat karena dosis awalnya yaitu $10 \mathrm{mg}$ dapat menurunkan tekanan darah dalam waktu 10 menit, amlodipin bekerja dengan menghambat influks kalsium pada sel otot polos pembuluh darah dan otot jantung sehingga terjadi relaksasi [14].

Berdasarkan Tabel 2 Sebanyak 41 pasien hipertensi tidak merokok mendapat pengobatan Amlodipine telah mengalami pengukuran dengan tensi digital sebanyak 3 kali. Hasil penelitian meunjukan bahwa Amlodipin mampu menurunkan rerata tekanan darah sistolik pada pasien hipertensi tidak merokok sebesar 4,15 $\mathrm{mmHg}$, sedangkan pada tekanan diastolik mengalami kenaikan rerata sebesar 1,32 $\mathrm{mmHg}$. Hasil penelitian ini berbeda dengan teori dan penelitian sebelumnya, karena pada penelitian sebelumnya yang diteliti oleh Baharuddin yang menyatakan bahwa Amlodipine dapat menurunkan tekanan darah pasien hipertensi sebesar 32,94/16,38 $\mathrm{mmHg}$, sedangkan pada penelitian ini hanya mampu menurunkan rerata tekanan darah sistolik sebesar 4,15 $\mathrm{mmHg}$ dan pada rerata tekanan darah diastolik tidak mengalami penurunan [7].

Sedangkan pada 36 pasien hipertensi perokok mendapat pengobatan Amlodipine dan telah mengalami pengukuran sebanyak 3 kali. Hasil penelitian menunjukan bahwa Amlodipine mampu menurunkan rerata tekanan darah sistolik pasien hipertensi perokok sebesar $1,38 \mathrm{mmHg}$, dan mampu menurunkan tekanan darah diastolik pasien hipertensi perokok sebesar 1,03 $\mathrm{mmHg}$. Hasil penelitian ini berbeda dengan teori dan penelitian sebelumnya bahwa pasien hipertensi perokok memiliki tekanan darah yang lebih tinggi dibanding pasien hipertensi tidak perokok.

Meskipun secara statistik takanan darah tidak ada perbedaan yang bermakna antara kelompok hipertensi tidak perokok dan kelompok hipertensi perokok, namun dapat kita lihat perbedaan rerata antara tekanan darah sistolik pada kelompok hipertensi tidak perokok dan hipertensi perokok, pada kelompok hipertensi tidak perokok dengan rerata tekanan darah sistolik dikisaran $\pm 140 \mathrm{mmHg}$, sedangkan pada kelompok hipertensi perokok dikisaran $\pm 150 \mathrm{mmHg}$. Hal ini menunjukan berbedaan secara klinis.

Mekanisme yang mungkin terjadi yang menyebabkan kelompok hipertensi perokok memiliki rerata tekanan darah lebih tinggi dibanding kelompok hipertensi tidak merokok disebabkan oleh zat yang terkandung dalam rokok. Seperti menurut penelitian sebelumnya oleh Leone, nikotin merusak sistem kardiovaskuler dengan cara mekanisme binding reseptor, hasil dari nikotinreceptorbinding menyebabkan stimulasi pada sistem saraf sympatik yaitu peningkatan lepasnya ketokolamin dan perubuhan rheologi viscositas, peningkatan dan perubahan tersebut menyebabkan peningkatan tekanan darah sistolik dan peningkatan denyut jantung serta disfungsi endothalium [15].

Tabel 3 menunjukan Efektivitas Terapi (Amlodipine) Hipertensi Perokok 
Berdasarkan Target Tercapainya Tekanan Darah Pada Hari ke-30 Pengukuran Tekanan Darah. Dalam guideline JNC 8 (2014) menyatakan penanganan hipertensi pada populasi pasien berumur 60 tahun keatas sulit untuk mencapai target tekanan $<140 / 90 \mathrm{mmHg}$, sehingga muncul target tekanan darah baru untuk usia diatas 60 tahun keatas yaitu $<150 / 90$ $\mathrm{mmHg}$, namun pada kenyataannya pada penelitian ini target tersebut juga masih sulit untuk dicapai [16].

$\begin{array}{ccc}\text { Pada kelompok kontrol } & \end{array}$ (hipertensi tidak perokok) yang seharusnya memiliki tekanan darah yang terkontrol ternyata efektifitas antihipertensi yaitu Amlodipin hanya efektif pada 18 orang responden $(43,9 \%)$ dari 41 responden, dan Amlodipin tidak efektif pada 23 orang $(56,1 \%)$ dari 41 responden, sehingga hanya 18 orang $(43,9 \%)$ hal ini membuat antihipertensi pada kelompok kontrol tidak efektif.

Tidak efektifnya antihipertensi Amlodipin pada kelompok kontrol (hipertensi tidak perokok) mungkin disebabkan oleh beberapa faktor yang tidak dapat dikontrol oleh peneliti. Faktor tidak efektifnya antihipertensi Amlodipin pada kelompok kontrol (hipertensi tidak tidak perokok) dimungkinkan karena faktor selain terapi farmakologi yaitu faktor stress, konsumsi lemak, konsumsi garam berlebihan seperti menurut Wells et all (2015) terapi hipertensi dilakukan dengan terapi farmakologi dan terapi nonfarmakologi, terapi non farmakolgi dilakukan dengan melakukan modifikasi gaya hidup [20].

Salah satu faktor seperti konsumsi lemak juga mempengaruhi peningkatan tekanan darah, seperti hasil penelitian Irza (2009) menyatakan bahwa faktor konsumsi lemak berhubungan dengan hipertensi yaitu makin sering mengkonsumsi makanan dengan tinggi lemak, maka tekanan darah juga akan semakin tinggi [17]. Faktor stres sulit tidur juga menjadi salah satu penyebab tekanan darah tetap tinggi seperti pada penelitian Sukadiyanto (2010) menyatakan individu yang mengalami stres sulit tidur akan berdampak pada tekanan darahnya yang cenderung tinggi [19]. Faktor konsumsi garam seperti penelitian sebelumnya Junaedi (2010) yang menyebutkan penyebab hipertensi adalah karena kondisi masyarakat yang banyak mmengkonsumsi garam yang cukup tinggi lebih dari 6,8 gram per hari [18].

Pada kelompok terpajan (hipertensi perokok) dari 36 responden antihipertensi Amlodipin hanya efektif pada 12 responden $(33,3 \%)$ dan tidak efektif pada 24 (66,7\%). Tidak efektifnya antihipertensi Amlodipin pada kelompok terpajan mungkin terjadi karena faktor merokok. Seperti dalam penelitian Syazana (2007) menyatakan bahwa ada hubungan antara lama merokok dengan kenaikan tekanan darah yang munkin pada penelitian ini menyebabkan antihipertensi Amlodipin tidak efektif [10].

\section{KESIMPULAN}

Pasien hipertensi dengan kebiasaan merokok memiliki efektivitas terapi amlodipin lebih rendah dibanding pasien hipertensi tanpa kebiasaan merokok, namun secara statistik tidak berbeda bermakna.

\section{UCAPAN TERIMA KASIH}

Kepada Pimpinan Puskesmas I Sumbang, Puskesmas II Kembaran, Puskesmas Purwokerto Timur I, Puskesmas Purwokerto Selatan, yang telah bersedia memberikan kesempatan untuk melakukan penelitian. 


\section{DAFTAR PUSTAKA}

[1]. Departemen Kesehatan Republik Indonesia. (2007). Riset Kesehatan Dasar. Jakarta.

[2]. Martin, T. (2011). Smoking and Atherosclerosis.

[3]. Narayana, I Putu Arya. Sudhana, I Wayan. (2013). Gambaran Kebiasaan Merokok dan Kejadian Hipertensi Pada Masyarakat Dewasa di Wilayah Kerja Puskesmas Pekutatan I. Jurnal, Universitas Udayana.

[4]. Departemen Kesehatan Republik Indonesia. (2013). Riset Kesehatan Dasar. Jakata.

[5]. Kurniati, Apriana Et al. (2012). Gambaran Kebiasaan Merokok dengan Profil Tekanan Darah pada Mahasiswa Perokok Laki-laki Usia 18-22 Tahun.Jurnal Kesehatan Masyarakat FKM Universitas Diponedoro. Volume1. No 1.

[6]. Sedayu, B. (2015). Karakteristik Pasien Hipertensi di Bangsal Rawat Inap SMF Penyakit dalam RSUP DR. M.Djamil Padang Tahun 2013. Jurnal Kesehatan. Universitas Andalas.

[7]. Baharuddin. Kabo, Peter. Suwandi, Danny. (2013). Perbandingan Efektivitas dan Efek Samping Obat Anti Hipertensi Terhadap Penuruna Tekanan Darah Pasien Hipertensi. Jurnal. Universitas Hasanuddin.

[8]. Departemen Kesehatan Republik Indonesia. (2015). Riset Kesehatan Dasar. Jakarta.

[9]. Sarampang Y. T, Tjitrosantoso H M, Citraningtyas g. (2014). Hubungan Pengetahuan Pasien Hipertensi tentang Obat Golongan ACE Inhibitor dengan Kepatuhan Pasien dalam Pelaksanaan Terapi Hipertensi di RSUP Prof Dr. R. D. Kondou Manado. Universitas Sam Ratulangi.

[10]. Syazana, Nur Adibah. (2007). Pengaruh Tekanan Darah pada Perokok di Kalangan Mahasiswa Lelaki Angkatan
2007 Fakultas Kedokteran Universitas Sumatra Utara. Skripsi. Universitas Sumatra Utara.

[11]. Manik, M. E. (2011). Faktor-Faktor yang Berhubungan dengan Hipertensi pada Lansia Wilayah Kerja Puskesmas Parsoburan Kecamatan Siantar Marihat Pematangsiantar Tahun 2011. Skripsi. Universitas Sumatra Utara.

[12]. Smantummkul, C. (2014). Tingkat Kepatuhan Penggunaan Obat Antihipertensi Pada Pasien Hipertensi Di Instalasi Rawat Jalan Rumah Sakit X Padaa Tahun 2014. Universitas Muhammadiyah Surakarta.

[13]. Violata, F. Leida, L. Thaha, Dwinata, L. (2015). Faktor Yang Berhubungan Dengan Kepatuhan Minum Obat Hipertensi di Wilayah Kerja Puskesmas Segiri. Universitas Hasanudin.

[14]. Nafrialdi. (2008). Antihipertensi dalam Farmakologi dan Terapeutik. Edisi 5. Departemen Farmakologi dan Terapeutik. Fakultas Kedokteran. Universitas Indonesia. Jakarta.

[15]. Leone, Aurelio. (2015). Smoking and Hypertension. Journal of Cardiologi \& Current Research. Volume (2) Issue (2).

[16]. Paul, A. et al. (2014). 2014 EvidanceBased Guideline for the Management of High Blood Pressure in Adults Report From the Panel Members Appointed to the Eight Joint National Committee. Clinical Review \& Education. Pages. 472, 474, 477.

[17]. Irza, Syukraini. (2009). Analisis Faktor Resiko Hipertensi pada Masyarakat Nagari Bungo Tanjung. Skripsi. Universitas Sumatra Utara.

[18]. Junaedi, I . (2010). Hipertensi. Gramedia. Jakarta.

[19]. Sukadiyanto. (2010). Stress dan Cara Menguranginya. http://core.ac.uk/

[20]. Wells, B. G., Dipiro, J. T., Schwinghammer, T. L., Dipiro, C. V. (2015). Pharmacotherapy Handbook. Ninth Edition. McGraw-HillEducation.

How to cited this article :

Mardena DR, Kusuma AM. 2017. Pengaruh Merokok terhadap Keefektivitasan Terapi Hipertensi pada Penderita Hipertensi Perokok di Empat Puskesmas Tahun 2017. J. Trop.Pharm. Chem. (4)2. 88-94 